STUDIA I PRACE WYDZIAŁU NAUK EKONOMICZNYCH I ZARZĄDZANIA nr 41, t. 2

\title{
Arvydas Survila*
}

Brigita Žuromskaitè**

Rūta Dačiulytė***

Uniwersytet im. Michała Romera w Wilnie, Litwa

\section{BEZPIECZEŃSTWO TURYSTÓW - ANALIZA POTENCJALNYCH ZAGROŻEŃ TURYSTYKI WYJAZDOWEJ Z LITWY}

\section{Streszczenie}

Turystyka jest jednym z najszybciej rozwijających się sektorów gospodarki. Turyści wybierają coraz to bardziej zróżnicowane kierunki podróży. To powoduje, że w trakcie wyjazdów mają do czynienia z wszelkiego rodzaju zagrożeniami. W niniejszym artykule podjęto analizę współczesnych zagrożeń w sektorze turystyki oraz aspektów bezpieczeństwa turystyki wyjazdowej z Litwy. Zostały omówione istniejące zagrożenia w popularnych i nowych kierunkach wyjazdów turystycznych.

Słowa kluczowe: bezpieczeństwo, turystyka wyjazdowa, Litwa

\section{Wprowadzenie}

Przemysł turystyczny zajmuje ważne miejsce w globalnej gospodarce. Corocznie zwiększa się liczba turystów oraz rozszerza geografia podróży. Będąc z dala od stałego miejsca zamieszkania, turyści mają do czynienia z wszelkimi zagrożeniami, dlatego przemysł turystyczny jest ściśle powiązany z ryzykiem spowo-

\footnotetext{
* E-mail: arvydas.survila@mruni.eu

** E-mail: brigita@wp.eu

*** E-mail: ruta.daciulyte@gmail.com
} 
dowanym przez zagrożenia istniejące w danym miejscu i czasie. Zapewnienie bezpieczeństwa turystom, identyfikacja zagrożeń zewnętrznych i wewnętrznych oraz zarządzanie sytuacjami nadzwyczajnymi - są to jedne z najważniejszych problemów w tej dziedzinie. Ich pomyślne rozwiązanie jest ważne zarówno dla usługodawcy, jak i konsumenta usług turystycznych.

W każdym państwie jest tworzony system zarządzania nadzwyczajnymi sytuacjami obejmujący pracę różnych sektorów, które mają na celu zapewnienie bezpieczeństwa nie tylko obywatelom państwa, lecz także turystom. Należy zauważyć, że choć cele takich systemów są podobne, ich struktury organizacyjne nie są jednakowo przygotowane do takich sytuacji (nawet na poziomie UE) ${ }^{1}$. Co więcej, współpraca organizacji różnych państw, zarządzających systemami sytuacji nadzwyczajnych nie jest jeszcze w pełni uregulowana, szczególnie na poziomie międzypaństwowym² ${ }^{2}$ Bezpieczeństwo turystów wyjeżdżających z kraju pozostaje stosunkowo na peryferiach tego systemu.

Jak wskazała analiza istniejącej sytuacji, jest to mało badany temat zarówno w literaturze ekonomicznej litewskiej, jak i literaturze zagranicznej. Bezpieczeństwo turystów dopiero w końcu XX wieku stało się obiektem zainteresowań naukowców badających specyfikę sektora turystycznego. Miało to znaczący wpływ na wybór celu niniejszego artykułu, którym jest omówienie współczesnych zagrożeń oraz aspektów bezpieczeństwa turystyki wyjazdowej z Litwy.

\section{Klasyfikacja i analiza zagrożeń}

Każda działalność, w tym także turystyka, jest powiązana z ryzykiem oraz zagrożeniami. Natomiast globalizacja, dostępność międzynarodowego transportu, globalne zmiany klimatu sprzyjają rozpowszechnianiu zagrożeń na znaczne terytorium.

W ramach oceny skutków ekonomicznych zagrożeń w turystyce najczęściej są rozpatrywane trzy podstawowe czynniki: liczba ofiar śmiertelnych, liczba osób rannych oraz straty materialne. Istniały propozycji zamiany tych czynników na jednostkę monetarną w celu otrzymania jednej liczby ukazującej skutki katastrofy, jednak powstał dylemat etyczny: jak ocenić ludzkiego życie ${ }^{3}$. Należy rów-

\footnotetext{
Europos Komisija. Žalioji knyga. Turistu apgyvendinimo paslaugu sauga, 2014, http://ec.europa.eu/dgs/ health_food-safety/dgs_consultations/ca/docs/cons_20141130_tourism_gp_lt.pdf_[dostęp 28.04.2015].

Tamże, s. 7.

H. Cochrane, The Economics of Disaster, Retrospect and Prospect, w: The Economics of Natural and Unnatural Disasters, ed. W. Kern, Upjohn Institute for Employment Research, Kalamazoo, Michigan 2010.
} 
nież zaznaczyć, że pośrednie straty katastrofy (np. upadek biznesu, zmniejszenie się dochodów i inne) są oceniane bardzo rzadko ${ }^{4}$.

Współcześnie w literaturze wyróżnia się trzy główne rodzaje zagrożeń: naturalne, technologiczne i umyślne . Warto zaznaczyć, że turyści mogą mieć do czynienia ze wszystkimi tymi zagrożeniami.

Jeden $\mathrm{z}$ tych rodzajów zagrożeń - zagrożenia naturalne ${ }^{6}$ - jest powiązany z konkretnymi miejscami geograficznymi (tabela 1). Warto zaznaczyć, że w ostatnich latach liczba tych zagrożeń znacznie wzrasta.

Tabela 1. Klasyfikacja zagrożeń naturalnych

\begin{tabular}{|l|l|}
\hline \multicolumn{1}{|c|}{ Zagrożenie według pochodzenia } & \multicolumn{1}{c|}{ Przykłady } \\
\hline $\begin{array}{l}\text { Geologiczne - powstające od procesów w skorupie } \\
\text { ziemi spowodowanych poprzez czynniki pochodzenia } \\
\text { endogennego, tektonicznego albo egzogenicznego }\end{array}$ & $\begin{array}{l}\text { - trzęsienia ziemi, tsunami } \\
\text { - wybuchy wulkanów i ich emisje } \\
\text { - osuwiska, lawiny kamieni, lawiny błotne } \\
\text { - obsunięcia ziemi }\end{array}$ \\
\hline $\begin{array}{l}\text { Hydrometeorologiczne - naturalne procesy albo } \\
\text { zjawiska zachodzace na skutek oddziaływania atmosfery, } \\
\text { zjawisk hydrologicznych albo oceanograficznych }\end{array}$ & $\begin{array}{l}\text { - powodzie, lawiny błota } \\
\text { śnieżyce, pioruny } \\
\text { - susze, pożary w przyrodzie, burze piaskowe albo } \\
\text { pyłowe, ekstremalny chłód, ekstremalne upały, huragany, } \\
\text { mgła, pioruny, lawiny śnieżne }\end{array}$ \\
\hline $\begin{array}{l}\text { Biologiczne - działanie pochodzenia organicznego albo } \\
\text { biologicznego, takie jak patogeniczne mikroorganizmy, } \\
\text { toksyny i biologicznie aktywne substancje, ich procesy }\end{array}$ & $\begin{array}{l}\text { - epidemie, ostre choroby epidemiczne, epidemie roślin } \\
\text { oraz rolnicze }\end{array}$ \\
\hline
\end{tabular}

Źródło: opracowanie własne na podstawie Living with Risk: A Global Review of Disaster Reduction Initiatives, United Nations Publications, New York-Geneva 2004, http:/www.unisdr.org/files/657_lwr1.pdf. [dostęp $23.03 .2015]$

Z kolei postęp technologiczny, rozwój przemysłu, wzrost gospodarczy, społeczne i polityczne czynniki przyczyniają się do powstania zagrożeń technologicznych. Są to takie zagrożenia, jak wypadki transportowe (lotnicze, kolejowe, drogowe), awarie infrastruktury (zaburzenia przepływu energii, sieci komputerowej, układu zaopatrzenia w wodę i kanalizacyjnego) oraz przemysłowe (np. w produkcji i przechowywaniu niebezpiecznych i radioaktywnych materiałów,

4 D.P. Coppola, Introduction to International Disaster Management, Butterworth-Heinemann, Burlington 2011; W. Kern, The Economics of Natural and Unnatural Disasters, Upjohn Institute for Employment Research, Kalamazoo, Michigan 2010.

5 Multi-Hazard Identification and Risk Assessment: A Cornerstone of the National Mitigation Strategy, 1997 , http://www.fema.gov/media-library-data/20130726-1545-20490-4487/mhira_in.pdf [dostęp 3.04.2015].

6 Na świecie na jednego człowieka, który zginął z powodu katastrofy, trafia 3000 osób, które ucierpiały od zagrożeń naturalnych. 
pożary itp. $)^{7}$. Jest to rodzaj zagrożeń, z którymi nie zawsze potrafimy skutecznie walczyć, ponieważ ich zakres jest bardzo szeroki, a one same trudne do przewidzenia. Warto podkreślić, że mogą nieraz wystąpić jako wtórne skutki przejawu zagrożeń naturalnych i obejmować bardzo zróżnicowane obszary. Jak wskazuje analiza sytuacji, w latach 2010-2014 zwiększyła się ich liczba i różnorodność. Jest to cena, którą płacimy za wygodne życie, w tym także za różnorodność i dostępność usług turystycznych.

Kolejna kategoria to tzw. celowe zagrożenia. Te, które wynikają nie z powodu awarii czy zdarzeń naturalnych, ale z przyczyn ludzkich. Współcześnie najbardziej znanym zagrożeniem tego typu jest terroryzm ${ }^{8}$ (tabela 2). Jego przyczyny są bardzo różne, na jego powstanie wpływa zarówno zaniedbanie interesów politycznych, kulturalnych, religijnych czy ekonomicznych poszczególnych grup, jak i dyskryminacja praw mniejszości narodowych, systematyczne łamanie praw człowieka, agresja militarna itp.

Nawet popularne centra turystyczne mają problemy z bezpieczeństwem (np. zagrożeniami kryminalnymi) ${ }^{9}$. Natomiast turyści jadą nie tylko do bezpiecznych miejsc, lecz także wybierają egzotyczne kierunki. Na listę państw o największym ryzyku terroryzmu wpisano Irak, Afganistan, Pakistan, Somalię, Nigerię, Jemen, Syrię, Filipiny, Liban, Libię, Kolumbie, Kenię ${ }^{10}$. Nie wpisano na nią dwunastu państw krajów europejskich, ale to nie oznacza, że w tych państwach nie występują akty terrorystyczne, w których mogą ucierpieć turyści. Warto pamiętać, że w ostatnich latach to właśnie turyści stają się celem ataków terrorystycznych i to nie tylko w ,niebezpiecznych” krajach.

7 J.B. Bumgarner, Emergency Management: A Reference Handbook, ABC-CLIO, 2008; D.P. Coppola, Introduction to International Disaster...; Encyclopedia of Crisis Management, ed. R. Hagen, M. Statler, K. Bradley Penuel, SAGE Publications, Thousand Oaks 2013.

8 Globalnie liczba ofiar ataków terrorystycznych w 2014 r. wzrosła o $30 \%$ w porównaniu ze średnią z poprzednich pięciu lat. W ciągu 12 miesięcy do 1 lipca odnotowano 18668 zgonów (o 29,3\% więcej niż średnia poprzednich pięciu lat - 14 433). W ciągu tego samego okresu odnotowano 9471 aktów terrorystycznych, jest ta liczba niższa niż poprzednia średnia pięciu lat, która wynosiła 10 468, zob. New Maplecroft Terrorism and Security Dashboard - Enhanced Global Threat Analysis and Dynamic Risk Mapping, 2014, http://maplecroft.com/portfolio/new-analysis/2014/06/18/new-maplecroft-terrorism-security-dashboardenhanced-global-threat-analysis-and-dynamic-risk-mapping/ [dostęp 3.05.2015].

9 Tourist safety and security. Practical Measures for Destinations, World Tourism Organization, 1996, http:// sete.gr/files/Media/Ebook/110301_Tourist\%20Safety\%20and\%20Security.pdf [dostęp 28.04.2015].

10 New Maplecroft Terrorism... 
Tabela 2. Źródła terroryzmu

\begin{tabular}{|l|l|}
\hline \multicolumn{1}{|c|}{ Wyszczególnienie } & \multicolumn{1}{|c|}{ Najbardziej znane organizacje } \\
\hline $\begin{array}{l}\text { Nacjonalistyczny terroryzm daży do } \\
\text { utworzenia niezależnego państwa }\end{array}$ & $\begin{array}{l}\text { Baskowie ETA, Irlandzka Armia Republikańska (IRA), Kurdyjska Partia } \\
\text { Robotnicza (Kurdistan Workers Party) w Turcji i północnym Iraku, } \\
\text { terrorystyczne organizacje Chalistan sikhów w Indii, Tamilskie Tygrysy } \\
\text { (Liberation Tigers of Tamil Eelam) na Sri Lance, francuski Front } \\
\text { Narodowego Wyzwolenia Korsyki (National Front for the Liberation of } \\
\text { Corsica) }\end{array}$ \\
\hline $\begin{array}{l}\text { Terroryzm religijny, którego celem jest } \\
\text { rozpowszechnianie swojej wiary poprzez } \\
\text { siłę, a także niszczenie niewierzacych albo } \\
\text { wierzących w innego Boga }\end{array}$ & $\begin{array}{l}\text { Abu Sajaf na Filipinach, sieć al-Kaidy na całym świecie, Ansar al-Islam } \\
\text { w Iraku, Islamska Grupa Zbrojna (Armed Islamic Group) itp. }\end{array}$ \\
\hline $\begin{array}{l}\text { Lewicowe organizacje terrorystyczne dążą } \\
\text { do zniszczenia systemu kapitalistycznego } \\
\text { i na jego miejscu utworzenia systemu } \\
\text { komunistycznego albo socjalistycznego }\end{array}$ & $\begin{array}{l}\text { niemiecki Badder-Meinhof Gang, japońska Armia Czerwona, włoskie } \\
\text { Czerwone Brygady }\end{array}$ \\
\hline $\begin{array}{l}\text { Prawicowy terroryzm stara się obalić } \\
\text { liberalny rząd i na jego miejscu utworzyć } \\
\text { reżim faszystowski }\end{array}$ & $\begin{array}{l}\text { Aryjskie Narody (Arian Nations), Russian National Unity, The National } \\
\text { Alliance }\end{array}$ \\
\hline $\begin{array}{l}\text { Celem terroryzmu anarchistycznego jest } \\
\text { zniesienie hierarchii społecznej }\end{array}$ & $\begin{array}{l}\text { Obecnie przedstawicielami terroryzmu anarchistycznego są nazywani } \\
\text { ekoterroryści i Earth Liberaton Front }\end{array}$ \\
\hline $\begin{array}{l}\text { Terroryzm jednej sprawy } \\
\text { Takie grupy chca zwrócić uwagę na to, w co wierza (ochrona } \\
\text { środowiska, ochrona praw zwierząt, opozycja przeciw aborcji) }\end{array}$ \\
\hline
\end{tabular}

Źródło: opracowanie własne na podstawie A. Paukštè, Terorizmas ir jo prevencija Lietuvoje, MRU, Vilnius 2006, s. 196 .

Podsumowując, należy zauważyć, że straty z powodu pojawiających się zagrożeń na świecie i liczba osób nimi dotkniętych ciągle rosną ${ }^{11}$. Straty wynikające z zagrożeń pojawiają się na wszystkich poziomach: od pojedynczych szkód gospodarstwa domowego, powiązanych z codziennymi zagrożeniami środowiska aż do nadzwyczajnych katastrof (np. trzęsienia ziemi i cyklony), które mogą mieć wpływ na straty dla całych regionów. Wszystkie straty są aktualne i ważne, ponieważ światowe tendencje pokazują, że zdarzenia przynoszą coraz więcej strat i potrzebne są coraz większe wydatki na rekompensatę szkód. Należy również podkreślić, że państwa słabsze ekonomicznie są bardziej narażone na ryzyko zagrożeń niż państwa bogatsze. Co oznacza, że turyści podróżujący do tych krajów szczególnie muszą dbać o swoje bezpieczeństwo.

11 A Global Report. Reducing Disaster Risk. A Challenge for Development, New York 2004, http://www.preventionweb.net/files/1096_rdrenglish.pdf [dostęp 3.04.2015]. 


\section{Powiązania tendencji i zagrożeń turystyki wyjazdowej Litwy}

Jak zauważają Pender i Sharpley ${ }^{12}$, zdarzenia przyrodnicze, ekonomiczne i polityczne mają ogromny wpływ na poziom turystyki w niektórych państwach. Duże zdarzenia nie raz już wpłynęły na drastyczne zmniejszenie frekwencji turystycznej oraz przyczyniły się do niepopularności niektórych kierunków podróży. Warto wspomnieć takie zdarzenia, jak 11 września 2001 w Nowym Jorku oraz 12-13 października 2002 na Bali, które miały istotny wpływ na liczbę przybywających turystów ${ }^{13}$. W ostatnich latach takie sytuacje są coraz częstsze oraz zwiększa się ich skala.

Na Litwie nie ma dużych zagrożeń, z którymi mogą mieć do czynienia turyści. Obywatele Litwy dosyć często jednak podróżują i wybierają nie tylko tradycyjne kierunki wakacji, lecz także bardziej egzotyczne (tabela 3).

Tabela 3. Liczba podróży oraz wyjeżdżających turystów litewskich w latach 2010-2013 według najpopularniejszych kierunków

\begin{tabular}{|c|c|c|c|c|c|c|c|c|}
\hline \multicolumn{7}{|c|}{ Liczba podróży wyjeżdżajacych turystów (tys.) } & \multicolumn{2}{c|}{$\begin{array}{c}\text { Liczba } \\
\text { wyjeżdżających } \\
\text { turystów (tys.) }\end{array}$} \\
\hline 2010 & 46,4 & 23,6 & 35,0 & 32,4 & 23,4 & 62,5 & 82,1 & 1206,7 \\
\hline 2011 & 28,6 & 29,2 & 53,6 & 33,1 & 24,5 & 55,7 & 96,1 & 1247,8 \\
\hline 2012 & 20,0 & 30,9 & 58,3 & 39,6 & 31,9 & 76,7 & 105,7 & 826,4 \\
\hline 2013 & 19,6 & 29,5 & 47,0 & 51,6 & 21,7 & 77,0 & 111,8 & 873,1 \\
\hline
\end{tabular}

Źródło: opracowanie własne na podstawie Głównego Urzędu Statystycznego Litwy, http://estatistika.stat.gov. lt [dostęp 23.04.2015].

Europa nadal pozostaje kontynentem najbardziej przez turystów odwiedzanym. W 2013 roku przybyło tu więcej niż $560 \mathrm{mln}$ turystów. Swój kontynent do zwiedzania najczęściej wybierają także i sami Europejczycy (w 2013 roku prawie $40 \%$ wakacje spędziło w UE $)^{14}$. Popularnymi kierunkami wśród turystów pozostają Włochy, Francja, Hiszpania, Grecja. Także obywatele Litwy najczęściej podróżują po Europie oraz wspomnianych krajach.

\footnotetext{
12 L. Pender, R. Sharpley, Zarzadzanie turystyka, PWE, Warszawa 2008, s. 332.

13 Tamże.

14 Europos Komisija. Žalioji...
} 
Większość turystów uważa Europę za bardzo bezpieczny kontynent, na co wskazują coroczne badania Eurobarometru ${ }^{15}$. Powstaje jednak pytanie, czy faktycznie tak jest. Jak widać w tabeli 4, ostatnich pięć lat w Europie nie było spokojnych pod względem klęsk żywiołowych.

Tabela 4. Przykłady dużych klęsk żywiołowych w Europie w latach 2010-2014

\begin{tabular}{|c|c|c|c|c|c|c|}
\hline \multirow{5}{*}{ 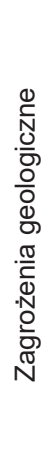 } & Rok & $\begin{array}{c}\text { Klęska } \\
\text { żywiołowa }\end{array}$ & Państwo & $\begin{array}{l}\text { Liczba ofiar } \\
\text { śmiertelnych }\end{array}$ & $\begin{array}{l}\text { Liczba osób } \\
\text { dotkniętych } \\
\text { szkodami }\end{array}$ & $\begin{array}{c}\text { Straty } \\
\text { (“000 USD) }\end{array}$ \\
\hline & 2010 & $\begin{array}{l}\text { wybuch } \\
\text { wulkanu }\end{array}$ & Serbia & 2 & 27030 & 132260 \\
\hline & 2010 & $\begin{array}{l}\text { wybuch } \\
\text { wulkanu }\end{array}$ & Islandia & - & - & - \\
\hline & 2011 & $\begin{array}{l}\text { wybuch } \\
\text { wulkanu }\end{array}$ & Hiszpania & 10 & 15300 & 132260 \\
\hline & 2012 & $\begin{array}{l}\text { wybuch } \\
\text { wulkanu }\end{array}$ & Włochy & 24 & 25350 & 1580000 \\
\hline \multirow{12}{*}{ 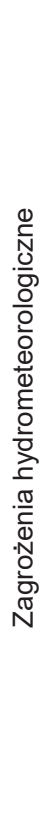 } & 2010 & burza & Francja & 53 & 500079 & 4230000 \\
\hline & 2010 & burza & Niemcy & 4 & - & 10000000 \\
\hline & 2011 & burza & Belgia & 5 & 71 & 99000 \\
\hline & 2012 & $\begin{array}{l}\text { ekstremalne } \\
\text { ochłodzenie }\end{array}$ & Rumunia & 86 & 7539 & - \\
\hline & 2012 & $\begin{array}{l}\text { ekstremalne } \\
\text { ochłodzenie }\end{array}$ & Serbia & 9 & 18234 & - \\
\hline & 2012 & susza & Włochy & - & 5800 & 4020000 \\
\hline & 2013 & burza & Szwajcaria & - & 84 & 250000 \\
\hline & 2013 & burza & Niemcy & 4 & - & 4800000 \\
\hline & 2013 & burza & Portugalia & 1 & 3967 & - \\
\hline & 2014 & powódź & $\begin{array}{l}\text { Wielka } \\
\text { Brytania }\end{array}$ & 2 & 600 & 1500000 \\
\hline & 2014 & powódź & Serbia & 51 & 16000000 & 2172355 \\
\hline & 2014 & burza & $\begin{array}{l}\text { Wielka } \\
\text { Brytania }\end{array}$ & 5 & 18000 & 100000 \\
\hline
\end{tabular}

Źródło: opracowanie własne na podstawie informacji The Centre for Research on the Epidemiology of Disasters, http://www.emdat.be/ [dostęp 3.04.2015].

15 Tamże. 
Również w latach 2010-2014 w Europie wystąpiły liczne wypadki i zagrożenia technologiczne: kolejowe (2010 Belgia, Buizingen, zginęło 18 osób, rannych 171; 2012 Holandia, w pobliżu Amsterdamu, zginęła 1 osoba, rannych 117; 2012 Polska, Szczekociny, zginęło 16, rannych 60; 2013 Hiszpania, Saint-Jacques de Compostelle, zginęło 79, rannych 140, straty $138 \mathrm{mln}$ USD); samochodowe, transportu wodnego (2011 Włochy, Lampedusa, zginęło 150, rannych 48; 2013 Włochy, między Lampedusą i Maltą, zginęło 50, rannych 200); lotnicze (2010 Rosja, niedaleko Smoleńska, zginęło 96) ${ }^{16}$. Należy także wyróżnić wypadki przemysłowe (2010 na Węgrzech, Ajka, wylały się niebezpieczne substancje chemiczne, zginęło 9, rannych 7270, straty 103 mln USD) ${ }^{17}$.

Tabela 5. Zagrożenia dla bezpieczeństwa według ulubionych kierunków podróży turystów z Litwy (2010-2014)

\begin{tabular}{|c|c|}
\hline Kraj & Statystyczne dane zdarzeń (liczba osób) \\
\hline \multirow{3}{*}{ 苂 } & $\begin{array}{l}\text { Terroryzm - prawdopodobieństwo ataków terrorystycznych, demonstracji i starć } \\
\text { pomiędzy protestującymi a siłami bezpieczeństwa (niebezpieczne obszary: Kair i inne } \\
\text { największe miasta Egiptu) }\end{array}$ \\
\hline & $\begin{array}{l}\text { Żywiołowe } \\
\text { trzęsienie ziemi - odczuło 250; ekstremalne ochłodzenie - } 3 \text { ofiary śmiertelne, rannych } \\
\text { - 10; powodzie (3) - zginęło 31, rannych 4300; epidemie (2) - zmarło 15, odczuło 143; } \\
\text { lawina skalna - zginęło 98, rannych } 697\end{array}$ \\
\hline & $\begin{array}{l}\text { Technologiczne } \\
\text { przemysłowe (wybuch, 3) - zginęło 29, dotkniętych } 2021 \text {, straty } 10 \text { mln USD; awarie } \\
\text { przemysłowe (4) - zginęło 62, rannych 446; różne awarie (12) - liczba ofiar śmiertelnych } \\
203 \text {, rannych } 862 \\
\text { wypadki: samochodowe (90) - zginęło 1509, rannych 1359; kolejowe (5) - zginęło 502, } \\
\text { rannych 529; wodne (8) - zginęło 1186, rannych } 412\end{array}$ \\
\hline \multirow{3}{*}{$\frac{\sqrt[\pi]{0}}{\frac{N}{5}}$} & Terroryzm - trwają zamieszki oraz istnieje prawdopodobieństwo ataków terrorystycznych \\
\hline & $\begin{array}{l}\text { Żywiołowe } \\
\text { trzęsienia ziemi (20) - zginęło 950, straty doznało } 654998 \text {, straty 1,974 mld USD; } \\
\text { ekstremalny chłód (2) - zmarło 24, dotkniętych 230; ekstremalne upały (2) - zmarło 14, } \\
\text { dotkniętych 300, straty } 1 \text { mln USD; powodzie (19) - zginęło 229, dotkniętych } 157955 \text {, } \\
\text { straty } 932 \text { tys. USD; osuwiska (5) - zginęło 48, dotkniętych 115; burze (7) - zginęło 39, } \\
\text { dotkniętych 4636; pożary leśne (3) - zginęło 2, dotkniętych 650 }\end{array}$ \\
\hline & $\begin{array}{l}\text { Technologiczne } \\
\text { przemysłowe (190 - zginęło } 633 \text {, dotkniętych } 647 \\
\text { transportu lotniczego (4) - zginęło } 240 \text {, dotkniętych 5; samochodowego (31) - zginęło } \\
551 \text {, dotkniętych } 603 \text {; kolejowego (3) - zginęło 62, dotkniętych } 70 \text {; wodnego (18) - } \\
\text { zginęło 500, dotkniętych } 79\end{array}$ \\
\hline
\end{tabular}

Źródło: opracowanie własne na podstawie informacji Ministerstwa Spraw Zagranicznych RL, http://www.urm. 1t/default/lt/ [dostęp 23.04.2015] oraz The Centre for Research...

16 The Centre for Research..

17 Tamże. 
Jednak coraz więcej turystów z Litwy podróżuje poza granice Europy. Wśród najpopularniejszych kierunków można wyróżnić Turcję i Egipt (tabela 5). Rozszerzenie geografii podróży zwiększa ryzyko oraz niebezpieczeństwo zagrożenia, dlatego na podstawie bazy danych Ministerstwa Spraw Zagranicznych Republiki Litewskiej oraz The Centre for Research on the Epidemiology of Disasters można wyróżnić zagrożenia, kryzysy oraz sytuacje nadzwyczajne, z jakimi mogą się zderzyć turyści podczas podróży do tych krajów.

Także wśród obywateli Litwy coraz popularniejsze stają się takie kierunki, jak Izrael, Indie oraz Tajlandia. Niestety, nie mamy konkretnych danych, ilu turystów podróżuje do tych państw. Jak wynika jednak z analizy ofert i sprzedaży biur turystycznych, liczba takich wycieczek wzrasta.

Przy podróżach na dalsze dystanse wzrasta ryzyko i zwiększa się lista potencjalnych zagrożeń (tabela 6). Ministerstwo Spraw Zagranicznych Republiki Litewskiej oraz Departament Turystyki przy Ministerstwie Gospodarki Republiki Litewskiej publikują listę i umieszczają informacje o krajach, do których podróż w danym czasie jest niebezpieczna, lecz turyści nie zawsze dostosowują się do tych zaleceń.

Dla lepszego zrozumienie zagrożeń i ryzyka ważna jest informacja, którą turyści mogą otrzymać o kierunkach podróży. Podstawowym źródłem informacji stają się media, biura podróży, spółki ubezpieczeniowe, przyjaciele oraz rodzina ${ }^{18}$. Także taką informację udostępniają urzędy państwowe. Niestety, w oficjalnych źródłach dostępna informacja o zagrożeniach jest jedynie fragmentaryczna oraz rozproszona. Brakuje jednego punktu, w którym byłaby zamieszczana wszelka informacja o zagrożeniach w poszczególnych krajach.

Problem ten dotyczy nie tylko Litwy. Uznaje się, że w całej UE brakuje informacji o faktycznym stanie bezpieczeństwa turystów ${ }^{19}$. Ponadto źródła danych w różnych państwach członkowskich nie są skoordynowane i zebrane dla wspólnego monitoring $\mathrm{u}^{20}$.

18 Tourist safety and security. Practical Measures for Destinations, World Tourism Organization 1996, s. 16, http://sete.gr/files/Media/Ebook/110301_Tourist\%20Safety\%20and\%20Security.pdf [dostęp 28.04.2015].

19 Europos Komisija. Žalioji...

20 Tamże. 
Tabela 6. Zagrożenia dla bezpieczeństwa według ulubionych kierunków podróży turystów z Litwy (2010-2014)

\begin{tabular}{|c|c|}
\hline Kraj & Statystyczne dane zdarzeń (liczba osób) \\
\hline \multirow{3}{*}{ 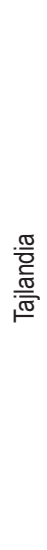 } & $\begin{array}{l}\text { Terroryzm } \\
\text { 1.04.2015 w Tajlandii anulowano trwający } 9 \text { miesięcy stan wojenny, jednak na mocy tymczasowej wojskowi } \\
\text { mają prawo wstrzymać wszelkie działania mogące stanowić zagrożenie dla pokoju i stabilności państwowej. } \\
\text { W miejscach publicznych, mocno odwiedzanych przez ludzi, możliwe ataki terrorystyczne. Niebezpieczne } \\
\text { terytoria: Pattani, Yala, Narathiwat i Songkhla. Nie zaleca się również wyruszać na terytoria znajdujące się obok } \\
\text { światyń Preah Vihear (w języku tajskim - Khaoi Pra Viharn) i Ta Krabey (Ta Moan) }\end{array}$ \\
\hline & $\begin{array}{l}\text { Żywiołowe } \\
\text { trzęsienia ziemi (2) - zginęły } 2 \text { osoby, dotkniętych } 17539 \text {, straty } 62 \text { mln USD; susza (6) - dotkniętych } \\
21482 \text { 602, straty } 422,3 \text { mln USD; ekstremalny chłód - zginęło 63, dotkniętych } 1 \text { mln; powodzie (46) - zginęło } \\
2229 \text {, dotkniętych } 36107 \text { 125, straty } 41895313000 \text { USD; burze (3) - zginęła } 1 \text { osoba, dotkniętych } 35 \\
\text { 204, straty } 2 \text { mln USD; cyklon - zginęło } 31 \text {, dotkniętych } 1048 \text { 219, straty } 20 \text { mln USD; tsunami - zginęło } \\
\text { 8345, dotkniętych } 67 \text { 007, straty } 1 \text { mld USD; epidemie (choroba bakteryjna albo wirusowa, 6) - zginęło 141, } \\
\text { dotkniętych } 40 \text { 573; pożary (6) - zginęło 120, dotkniętych 4929, straty 3,517 mln USD }\end{array}$ \\
\hline & $\begin{array}{l}\text { Technologiczne } \\
\text { transportu lotniczego (3) - zginęło 111; wypadki samochodowe (19) - zginęło 389, dotkniętych 436; } \\
\text { transportu wodnego (6) - zginęło 99, dotkniętych 65; wypadki kolejowe (2) - zginęły 3, dotkniętych } 300\end{array}$ \\
\hline \multirow{3}{*}{$\underset{\mathbb{N}}{\mathbb{N}}$} & $\begin{array}{l}\text { Terroryzm - z powodu trwającej fali przemocy sytuacja na starym mieście i we wschodniej Jerozolimie ciagle } \\
\text { pozostaje napięta. Niebezpieczne terytorium: wschodnia Jerozolima (Ras al-Amud, At-Tur/Mount of Olives, } \\
\text { Wadi Al-Joz, Silwan i inne), Strefa Gazy oraz obszar przygraniczny z Syrią i Libanem }\end{array}$ \\
\hline & $\begin{array}{l}\text { Żywiołowe } \\
\text { burze (2) - zginęło 7, dotkniętych } 2003 \text { 410, straty 2,750 mln USD; epidemia (choroba wirusowa, 1) - zginęło } \\
\text { 12, dotkniętych 139; pożar leśny - zginęło 44, dotkniętych } 20 \text { 022, straty } 270 \text { mln USD }\end{array}$ \\
\hline & $\begin{array}{l}\text { Technologiczne } \\
\text { samochodowe - zginęło 24, dotkniętych 28; kolejowe - zginęło 7, dotkniętych } 200\end{array}$ \\
\hline \multirow{3}{*}{ 음 } & $\begin{array}{l}\text { Terroryzm, choroby oraz przestępczość - ryzyko ataków ekstremistycznych w następujących obszarach: na } \\
\text { pograniczu z Pakistanem (stany Dżammu i Kaszmir, z wyjąkiem regionu Ladakh), we wschodnich i centralnych } \\
\text { stanach Indii (Manipur, Tripura, Assam, Nagaland, Bihar, Jharkand, Chhattisgarh, zachodnia Bengalia, Orisa). } \\
\text { Szanse na ataki szczególnie wzrastają podczas świat indyjskich: Dzień Republiki, Holi, Dzień Niepodległości, } \\
\text { Ramadan, Eid-ul-Fitr (koniec Ramadanu), Divali. W dużych miastach (Delhi, Kalkuta, Bombaj) się kradzieże } \\
\text { oraz występują zorganizowane nieuzbrojone rozboje. Zagrożenia zdrowia i życia kobietom }\end{array}$ \\
\hline & $\begin{array}{l}\text { Żywiołowe } \\
\text { trzęsienia ziemi (5) - zginęło } 21431 \text {, dotkniętych } 7113 \text { 184, straty 3,743 mld USD; susza (3) - zginęło } \\
\text { 20, dotkniętych } 350 \text { mln, straty } 1498722000 \text { USD; ekstremalny chłód - zginęło 63, dotkniętych } 1 \text { mln; } \\
\text { powodzie (123) - zginęło } 21 \text { 855, dotkniętych } 266520 \text { 418, straty } 38242347000 \text { USD; burze (3), zginęła } \\
\text { 1 osoba, dotkniętych } 35 \text { 204, straty } 2 \text { mln USD; cyklon - zginęło 31, dotkniętych } 1048 \text { 219, straty } 20 \text { mln USD; } \\
\text { epidemie (39) - zginęło 2139, dotkniętych } 49838767 \text {; straty } 131 \text { mln USD; ekstremalny chłód (15) - zginęło } \\
\text { 2548, dotkniętych 25; ekstremalne upały (9) - zginęło 3622, dotkniętych 25, straty } 400 \text { mln USD; pożary (27) - } \\
\text { zginęło 676, dotkniętych } 26 \text { 940, straty } 410 \text { mln USD }\end{array}$ \\
\hline & $\begin{array}{l}\text { Technologiczne } \\
\text { przemysłowe (15) - zginęło 360, dotkniętych 2792, straty } 200 \text { mln USD; } \\
\text { transportu lotniczego (7) - zginęło 304; samochodowego (103) - zginęło 3080, dotkniętych 1876; wodnego (30) } \\
\text { - zginęło 1286, dotkniętych 366; kolejowego (45) - zginęło 1218, dotkniętych 366, straty } 2 \text { mln USD }\end{array}$ \\
\hline
\end{tabular}

Źródło: opracowanie własne na podstawie informacji Ministerstwa Spraw Zagranicznych RL... ;

The Centre for Research.. 


\section{Podsumowanie}

W codziennej działalności człowiek zderza się z licznymi zagrożeniami. Turyści podróżujący do innego państwa albo we własnym kraju niezależnie od tego, czy są świadomi, czy nie - stale są wystawieni na ryzyko. Częstotliwość wystąpienia zagrożenia zależy od położenia geograficznego, wydarzeń bądź warunków fizycznych, od ruchu w przestrzeni, ludzkiej działalności czy przypadkowości. Według pochodzenia zagrożenia dzielą się na zagrożenia naturalne, technologiczne i umyślne. Zagrożenia stwarzają nadzwyczajne sytuacje mające różnorodne konsekwencje zarówno dla jednostki, jak i społeczeństwa. Wielkość tych konsekwencji charakteryzuje liczba ofiar śmiertelnych, liczba osób dotkniętych tragedią i ogólna cena strat podawana w jednostkach pieniężnych.

W sektorze turystyki zauważalny jest wzrost sytuacji nadzwyczajnych, ponieważ z powodu globalizacji i wzrostu mobilności turystów rozszerza się spektrum podróży, zwiększa się ich niebezpieczeństwo. Zmienia się również charakter podróży, zwiększa się liczba wycieczek bez korzystania z usług biur podróży. Uczestnicy turystyki wyjazdowej często znajdują się w trudnej sytuacji, ponieważ nie są widoczni dla systemów zarządzania sytuacjami nadzwyczajnymi ani własnego państwa, ani państwa docelowego, dlatego ich gotowość do samodzielnej redukcji kryzysu, nieszczęścia jest bardzo ważna. Analiza źródeł wskazuje, że turyści nie zawsze właściwie oceniają zagrożenia podróży i własne bezpieczeństwo. Możliwie, że wpływ na to mają trudności w dotarciu do wiarygodnych informacji oraz oceny faktycznego zagrożenia.

\section{Literatura}

A Global Report. Reducing Disaster Risk. A Challenge for Development, New York 2004, http://www.preventionweb.net/files/1096_rdrenglish.pdf.

Bumgarner J.B., Emergency Management: A Reference Handbook, ABC-CLIO, 2008.

Cochrane H., The Economics of Disaster, Retrospect and Prospect, w: The Economics of Natural and Unnatural Disasters, ed. W. Kern, Upjohn Institute for Employment Research, Kalamazoo, Michigan 2010.

Coppola D.P. Introduction to International Disaster Management, Butterworth-Heinemann, Burlington 2011.

Encyclopedia of Crisis Management, ed. R. Hagen, M. Statler, K. Bradley Penuel, SAGE Publications, Thousand Oaks 2013.

Europos Komisija. Žalioji knyga. Turistu apgyvendinimo paslangu sauga, 2014, http:// ec.europa.eu/dgs/health_food-safety/dgs_consultations/ca/docs/cons_20141130_ tourism_gp_lt.pdf. 
Główny Urząd Statystyczny Litwy, http://estatistika.stat.gov.lt.

Kern W., The Economics of Natural and Unnatural Disasters, Upjohn Institute for Employment Research, Kalamazoo, Michigan 2010.

Living with Risk: A Global Review of Disaster Reduction Initiatives, United Nations Publications, New York-Geneva 2004, http://www.unisdr.org/files/657_lwr1.pdf.

Ministerstwo Spraw Zagranicznych Litwy, http://www.urm.lt/default/lt.

Multi-Hazard Identification and Risk Assessment: A Cornerstone of the National Mitigation Strategy, 1997, http://www.fema.gov/media-library-data/201307261545-20490-4487/mhira_in.pdf.

New Maplecroft Terrorism and Security Dashboard - Enhanced Global Threat Analysis and Dynamic Risk Mapping, 2014, http://maplecroft.com/portfolio/ new-analysis/2014/06/18/new-maplecroft-terrorism-security-dashboardenhanced-global-threat-analysis-and-dynamic-risk-mapping.

Paukštė A., Terorizmas ir jo prevencija Lietuvoje, MRU, Vilnius 2006.

Pender L., Sharpley R., Zarządzanie turystyka, PWE, Warszawa 2008.

The Centre for Research on the Epidemiology of Disasters, www.emdat.be.

Tourist safety and security. Practical Measures for Destinations, World Tourism Organization, 1996, http://sete.gr/files/Media/Ebook/110301_Tourist\%20Safety\%20 and $\% 20$ Security.pdf.

\title{
TOURISTS SAFETY: THE ANALYSIS OF POTENTIAL THREATS OF LITHUANIAN OUTBOUND TOURISM TRENDS
}

\begin{abstract}
Tourism is one of the fastest developing sectors of the economy. Tourists gather more and more diverse travel destinations. In our days during the travel time tourists deal with increasingly wider variety of threats. This paper analyzes modern threats faced by tourists departing from LTU. As well the paper analyzes the main threats tourists may encounter on the most popular tourists destinations.
\end{abstract}

Translated by Arvydas Survila, Brigita Žuromskaitè, Rūta Dačiulytè

Keywords: tourism, security, outbound tourism, Lithuania

JEL code: L83 